\title{
Näkökulmia mediakuvien arkeen
}

Janne Seppänen (2005). Visuaalinen kulttuuri. Teoriaa ja metodeja mediakuvan tulkitsijalle. Vastapaino.

Tampereen yliopiston tiedotusopin professori Janne Seppäsen kirjan nimi, visuaalinen kulttuuri, viittaa laaja-alaiseen tutkimussuuntaukseen. Teos lohkaisee siitä siivun etenkin niille, jotka haluavat tutustua aiheeseen yhteiskuntatieteellisestänäkökulmasta. Kirjassa käsiteltävät mediakuvatovat usein käyttökuvaa: lehtikuvia tai mainoksia. Kuvataide, arkkitehtuuri ja mediateknologia on rajattu ulkopuolelle. Teos sopisikin parhaiten journalismin tutkimuksen perusoppikirjaksi, tai yleisemmin johdatukseksi tutkimussuuntauksen historiaan.

Kirjan alussa esitellään tiiviisti perusteoriat visuaalisen kulttuurin tutkimuksen taustalla ja pohditaan alan muotoutumista 1990-luvulta eteenpäin. Visuaalinen kulttuuri kiteytetään ideologian, identiteetin, subjektin, katseen, tekijyyden, sukupuolenja vallanteemoihin, joita käsitellään tuttujen esimerkkien kautta, kuten Myyrmannin vuoden 2004 pommiräjähdyksen, internetin välityksellä levinneiden Irakin vankilakuvien, Dallas-TV-sarjan sekä sukupuolen ja rodun koodeilla pelaavien Benetton-mainosten avulla. Ajankohtaisten aiheiden käsittely tekee tekstistä mukaansatempaavaa. Esimerkit ovat selkeitä ja helppolukuisia myös akateemisiin tutkimuksiin perehtymättömälle; niissä lähdetään konkreettisista kuvista ja teksteistä.
Seppänen ratkaisee vaikeasti määriteltävän asian, kuvan, merkityksen tulkitsemalla sitä suhteessa kirjoitettuun tekstiin. Ajatus on, että kuvat ja tekstit muokkaavat toistensa merkityksiä visuaalis-tekstuaalisella kentällä ja rakentavat todellisuutta. Sitä selventää esimerkki Myyrmannin pommiturman uutisoinnista: tekijän passikuvia ja luokkakuvia käytettiin "yksinäisen suden" tarinan luomiseen.

Kirja on jaettu kuuteen, yhtä tutkimusotetta kerrallaan käsittelevään kappaleeseen. Alun representaatiotaja semiotiikkaa käsittelevissä kappaleissa pohditaan yksittäisiä kuvia ja niihin liittyviä tekstejä. Loppua kohden painottuvat selkeämmin mediakuvan tuotannon ja vallan kysymykset.

Sisällönanalyysi tuo esiin kuvallisuuden laajemmat rakenteet. Sitä käsitellään selkeästi, arjen kokemuspiiristä tuttujen ilmiöiden kautta, kuten valkoihoisten nuorten naisten kasvojen "yliedustus" lehtien kansikuvissa.

Vastaanottotutkimus-kappaleessa puolestaan tuodaan esille tulkitsijoiden ja tulkintojen moninaisuus, joka voi avata tutkimukselle uusia, ennalta arvaamattomia näkökulmia. Kuvatuotannon arjesta ja vallasta kirjoittaessaan Seppänen kytkee visuaalisen kulttuurin ranskalaisfilosofi Michel Foucault'n ajatteluun, jossa keskeistä on ajatus vallasta tuottavana voimana. Hyvä esimerkki on Maailman ihanin tyttö- projekti, jossa lastenkodissa varttuneet tytöt ideoivat ja valitsevat ammat- tivalokuvaajan toteuttamat kuvat, joissa tytöt itse esiintyvät sellaisina, kuin haluavat itsensä kuvattavan. Projektin tavoite on määritellä katsominen ja oma ulkonäkö positiivisesti omista lähtökohdista. Siinä risteää toimintatutkimus, valokuvataide ja terapeuttinen identiteettiprojekti, sukupuolen ja katseen merkitysten uudelleenarviointi, valta ja vastustus.

Myös kuvajournalistisia käytäntöjä voi tarkastella tämän tyyppisistä lähtökohdista. Seppänen esitteleekin teoksessaan paljon myös kuvajournalismin käytäntöjen tutkimista. Hän huomauttaa, että mediakuvastojen tuotanto ulottuu "mediatalojen kamppailusta skeittailijoiden videoihin".

Kirjan nimen vuoksi sitä lähestyy mielessään yleisempiäkin kysymyksiä siitä, millaista visuaalisuutta on, miksi sen tarkastelu on tärkeää, ja kenelle? Entä miten jäsentää kokemuksia siitä, mikä on kaunista, miellyttävää, vaivaannuttavaa tai ahdistavaa katsoa? Tai uutta arjen kuvatulvaa internetistä kamerakännyköihin? Arjen visuaalisuuden monimuotoisuudesta muistuttaa vielä johdantokappaleen esitys tavaratalon tilallisesta visuaalisena järjestyksenä, jossa lukijaa houkutellaan mukaan esimerkein hyllyjärjestyksistä meikkaamiseen. Näitä ei kirjasta kuitenkaan löydy, vaan painopiste on melko perinteissä kuvassa: valokuvassa ja lehtikuvassa.

Välillä näyttää siltäkin, että puheena ovat visuaalisen ympärillä olevat asiat: tekstit, tuotanto, valtasuhteet, mutta visuaa- 
linen itse tuntuu jäävän taustalle. Nykyaikaisen kuvallisuuden korostamista olisikin kaivannut enemmän, tai sitten toivoisi selkeämpiä äänenpainoja valittujen näkökulmien puolesta. Parhaiten ja innostavimmin Seppä- nen onnistuu mielestäni kuvatuotannon, tulkintojen, vallan ja vastustuksen teemojen esiin nostamisessa: esimerkit monitulkintaisista Benetton-mainoksista ja kuvien tuotannon rutiineja kyseenalaistavasta Maail- man ihanin tyttö-projektista voisi soveltua kiinnostavasti muillekin nykykuvallisuuden alueille. 